\title{
Thioredoxins induce oocyte maturation in holothuroids (Echinodermata)
}

\author{
Aline Leonet $^{\mathrm{ab} \$}$, Jérôme Delroisse ${ }^{\mathrm{a} \$}$, Christopher Schuddinck ${ }^{\mathrm{a}}$, Ruddy Wattiez ${ }^{\mathrm{c}}$, Michel \\ Jangoux $^{\mathrm{a}, \mathrm{d}}$, and Igor Eeckhaut ${ }^{\mathrm{a}, \mathrm{e}}$ \\ ${ }^{a}$ Biology of Marine Organisms and Biomimetics Unit, University of Mons - UMONS, 7000 Mons, Belgique \\ ${ }^{b}$ Haute Ecole du Hainaut, HEH, 7000 Mons, Belgique \\ ${ }^{c}$ Proteomics and Microbiology Lab, University of Mons - UMONS, 7000 Mons, Belgique \\ ${ }^{d}$ Marine Biology Laboratory, Free University of Brussels, 1050 Bruxelles, Belgique \\ e Polyaquaculture Research Unit, Institut Halieutique et des Sciences Marines, University of Toliaria, 601 \\ Tuléar, Madagascar \\ $\$$ The first two authors should be considered as co-first authors \\ *Address of correspondance: Prof. Igor Eeckhaut, Laboratoire de Biologie des Organismes Marins et \\ Biomimétisme, UMONS, Avenue du Champ de Mars 6, 7000 Mons; Tel. +32(65) 37 34, email: \\ igor.eeckhaut@umons.ac.be
}

\begin{abstract}
Chromatographic fractions of a rough extract of echinoid spawn (REES) has been demonstrated to efficiently induce oocyte maturation in aspidochirote holothuroids. The method is so efficient that it is now used in holothuriculture to get fertilised eggs even outside the reproductive period of the aquacultured species. We here isolate and identify from echinoid spawns the molecule responsible for the induction of the oocyte maturation in the Mediterranean holothuroid Holothuria tubulosa and the Indo-Pacific Holothuria scabra. The use of proteinase $\mathrm{K}$ and dialysing membranes indicates that the active molecule is a protein with a molecular weight superior to $12,000 \mathrm{kDa}$. The active molecule has been isolated on G100 Sephadex chromatography column. Active chromatographic fractions include seven proteins identified with nanoLC-MS/MS technique. One of them, identify as a thioredoxin-2 and to which the name Trx-REES has been given, leads up to levels of maturation similar to those obtained with the REES and with a commercial thioredoxin extracted from Escherichia coli. Occurrence of thioredoxin in REES was confirmed by immunoblot analysis, and the maturation-inducing properties of thioredoxin were positively checked in using antithioredoxin antibodies. A peptide of 6 AAs corresponding to the active site of Trx-REES, composed of WCNPCK, was synthesised and its efficiency in holothuroid oocyte maturation tested. At some concentrations, the peptide was 1.2 times more active than the REES.
\end{abstract}


Key words: holothuriculture, sea cucumber, oocyte maturation, sea urchin, thioredoxin

\section{Introduction}

In holothuroids, oocyte maturation that begins in the ovaries is stopped in the prophase-I stage of meiosis (Maruyama, 1980; McEuen, 1988) and the fertilisation only occurs when the oocytes are mature, i.e. after the two maturation divisions. Under natural conditions, meiotic resumption arrives just before spawning and leads to the completion of oocyte maturation (Costello et al., 1957). Cytoplamic molecules involved in the resumption of holothuroid oocyte maturation are still unknown but it is often suggested that the mechanism of meiotic release in sea cucumbers is relatively close to the one described in sea stars or in sea urchins (Maruyama, 1985; McEuen, 1988; Pearse and Cameron, 1991; Kanatani, 1974).

Attempts to identify the gonad-stimulating substance (GSS) and maturation-inducing substance (MIS) in holothuroids have yielded interesting results but never reached a precise identification. A peptide of several thousand Daltons was isolated from the radial nerve of five species of sea cucumber with the same properties as a GSS (Maruyama, 1985), but no more information about its sequence was detailed at that time. More recently, a GSS-like, isolated from the radial nerve of Apostichopus japonicus (Aj-GSSL) was characterised. This peptide of $4.8 \mathrm{kDa}$ induces GVBD to $80 \%$ of immature ovarian oocytes (Katow et al., 2009). At the same time, Kato et al. (2009) aimed to purify and identify a GSS-like substance involved in inducing holothuroid oocyte maturation. Among the large diversity of neuropeptides now described in echinoderms (e.g. Zandawala et al., 2017) and sea-cucumbers in particular (Suwansa-ard et al., 2018), Kato et al. (2009) found one peptide, the Cubifrin-I (NGIWYamide) produced by the radial nerve that induces oocyte maturation, ovulation and spawning in A. japonicus and synthesised a derivative, Cubifrin-L (NGLWYamide), that is even more active than the natural product (Fujiwara et al., 2010). The Cubifrin-I peptide, also discovered in the transcriptomes of Holothuria scabra and Holothuria glaberrima (Suwansaard et al., 2018), has not been tested in species belonging to the Holothuria genus, yet.

Many scientists have attempted to search for the holothuroid MIS, but so far the search has been unsuccessful. Smiley (1988) suggests that the MIS of Stichopus californicus is likely to be a 2,8-disubstituted adenine, however this has never been confirmed. There is a striking similarity between the mode of endocrine control in sea stars and holothuroids, which suggests that the holothuroid MIS has a chemical structure similar to 1-Methyl Adenine 
(1MeA), the MIS of sea stars (Smiley, 1990). It was demonstrated that 1-MeA failed to produce GVBD in Stichopus californicus (Hufty and Schroeber, 1974), S. japonicus (Kishimoto et al., 1982), Holothuria leucospilota and H. pardalis (Maruyama, 1980), H. scabra (Léonet et al., 2009) and Leptosynapta inhaerens (Ikegami et al., 1976). Various molecules miming 1-MeA in sea stars, like dithiothreitol (DTT) (Kishimoto et al., 1976), dimercapto-propanol (BAL) (Kishimoto and Kanatani, 1973) and L-cysteine (Kishimoto and Kanatani, 1980), were also tested to induce holothuroid oocyte maturation. DTT, a disulfidereducing agent, is the most effective (Kishimoto and Kanatani, 1973; Maruyama, 1980), but it induced major larval abnormalities (Chen et al., 1991; Kishimoto \& Kanatani, 1973; Holland, 1991). Despite these findings, the endocrine substances involved in natural holothuroid oocyte maturation remain unknown.

We have shown that a chromatographic fraction of a rough extract of echinoid spawn (hereafter REES) induces holothuroid maturation and fertility without provoking larval malformation (patent number: WO 2008/003691; patent title: "oocyte maturation method") (Léonet et al., 2009). The Maturation Inducing Fraction (MIF), extracted from the REES, are particularly powerful as it leads to the maturation of more than $90 \%$ of the stage $\mathrm{V}$ oocytes (see Rasolofonirina et al., 2005 for the description of the oocyte stages of $H$. scabra) extracted from the gonads of dissected individuals. It is active on all the tested aspidochirotes holothuroids (13 species) and at all periods of the year on H. scabra (Léonet et al., 2009). The maturation is so efficient that it is now used as a maturation inducer in holothuriculture for getting fertilised eggs and larvae even outside the reproductive period of the aquacultured species (Eeckhaut et al., 2012).

Amongst the molecules that compose the MIF, it is obvious that only a part of the molecules that it contains, and probably just one is responsible for the holothuroid oocyte maturation induction. We here describe the isolation and identification of the molecule in the rough extract of echinoid spawn that induces the oocyte maturation in holothuroids. We also identify the active site of the molecule, synthesise it and tested its efficiency in the maturation process.

\section{Materials and Methods}

Tested organisms and preparation of the maturation inducing fraction

The main used species was Holothuria tubulosa Gmelin, 1788 collected by SCUBA 
diving in the natural reserve of Banyuls-sur-Mer (France). The sea cucumbers were sent to the Laboratory of Marine Organisms and Biomimetics of the University of Mons (Belgium) and kept in closed circulating cold seawater until experimentations. Experiments were also conducted at the Aqua-Lab laboratory in Toliara (Madagascar). There, the experiments were carried out on the tropical sea cucumber Holothuria scabra Jaeger, 1833. Individuals were hand-collected at low tide in the sea grass beds of the Great Reef of Toliara. Living specimens were kept in aquaria supplied with circulating seawater.

To obtain the REES, regular sea urchins Tripneustes gratilla (Linnaeus, 1758) were collected by hand at low tide in the sea grass beds of the Great Reef of Toliara. Female spawns were obtained in shaking individuals vigorously. The spawns were centrifuged at $5,000 \mathrm{rpm}$ for $2 \mathrm{x} 10 \mathrm{~min}$, the pellet was recovered, then frozen, lyophilised (24h) and reduced into powder. To obtain active REES, the powder was dissolved in a Tris- $\mathrm{HCl}$ buffer $25 \mathrm{mM}$, $\mathrm{pH} 7.2, \mathrm{NaCl} 125 \mathrm{mM}$ in appropriate concentration $\left(2 \mathrm{mg} \mathrm{ml}^{-1}\right)$ and filtered on Whatman paper before use.

The induction of maturation was measured on holothuroid oocytes that were obtained from the ovaries of dissected individuals. The ovaries were isolated and washed several times with filtered seawater, then cut into pieces to release the oocytes from gonadal tubules. The

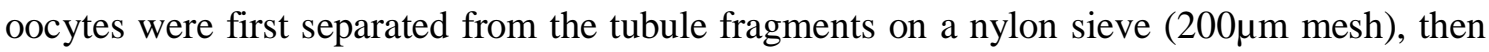
washed three times with filtered sea water on a smaller sieve $(100 \mu \mathrm{m}$ mesh). Isolated oocytes were incubated in Petri dishes (concentration: 100 oocytes $/ \mathrm{ml}$ ) in presence of REES (concentration $2 \%$ ) or in presence of a fraction of the REES (see hereafter).

The maturation of sea cucumber oocytes was monitored by observing the germinal vesicle breakdown (GVBD) and the formation of polar bodies with a light microscope after an incubation time of $2 \mathrm{~h}$. The portion of mature oocytes was determined by randomly counting from 100 to 150 oocytes per sample. In all experiments, to determine the percentage of spontaneous maturation, a portion of isolated oocytes was incubated in filtered seawater without any additives. The percentage of holothuroid oocytes that mature spontaneously is variable among individuals and according to the season (experiments were made in and out the spawning period). To standardise the results, the number of mature oocytes was expressed through a Maturation index (MI). MI was the number of mature oocytes in various solutions (e.g. solution with a fraction of the REES) divided by the number of mature oocytes in positive control. The number of oocytes that mature in REES was the positive control (with this transformation the MI in REES was always equal to 100). 
Fertilisation assays were performed by adding one drop of sperm suspension (concentration of spermatozoa: $c a 100.000 / \mathrm{ml}$ ) per 150ml. Sperm was obtained from isolated testes that were cut into pieces in filtered seawater. Sperm suspension in seawater was prepared no later than one hour before experiments. Experiments were carried out at seawater temperature $\left(20-23^{\circ} \mathrm{C}\right.$ for $H$. tubulosa and $23-28^{\circ} \mathrm{C}$ for $H$. scabra).

\section{Identification and characterisation of oocyte maturation-inducer}

Sample preparation by dialysis: $5 \mathrm{ml}$ of REES with a concentration of $2 \mathrm{mg} \mathrm{ml}^{-1}$ was dialysed (Spectra/Por Dialysis Membrane, Cutoff: 12-14kDa, Spectrum) three times against Tris- $\mathrm{HCl}$ buffer $25 \mathrm{mM}, \mathrm{pH} 7.2, \mathrm{NaCl} 150 \mathrm{mM}$ for $48 \mathrm{~h}$ at $4^{\circ} \mathrm{C}$. After this time, samples were tested on sea cucumber oocytes.

Proteolysis: A proteolytic digestion of REES $\left(2 \mathrm{mg} \mathrm{ml}^{-1}\right)$ was carried out at $40^{\circ} \mathrm{C}$ for $3 \mathrm{~h}$ by addition of proteinase $\mathrm{K}(0.01 \mathrm{mg} / \mathrm{ml})$. Proteolysis was stopped by boiling the samples for 30min. The control was conducted using REES in the same conditions without proteinase $\mathrm{K}$.

Chromatography: The REES was fractionated by chromatography on Sephadex G100. Sephadex G-100 was hydrated, equilibrated with a Tris-HCl buffer $25 \mathrm{mM}, \mathrm{pH} 7.2, \mathrm{NaCl}$ 150mM and packed into an XK 26/100 Pharmacia column (Biosciences Amersham). Twenty $\mathrm{ml}$ of sample $\left(50 \mathrm{mg} \mathrm{ml}^{-1}\right.$ ) were loaded onto a column and eluted with a Tris-HCl buffer $25 \mathrm{mM}, \mathrm{pH} 7.2, \mathrm{NaCl} 150 \mathrm{mM}$. A flow rate of $50 \mu \mathrm{l} / \mathrm{min}$ was obtained with a pump-1 (Biosciences Amersham). A FC204 fraction collector (Gilson FC250) was programmed to collect $4 \mathrm{ml}$ per sample. The fractions were used immediately or frozen at $-20^{\circ} \mathrm{C}$ for storage. To determine the active fractions, each fraction was assayed on holothuroid oocytes.

Protein highlighting: The protein concentration of each fraction was measured using the Bradford method. To estimate the purity of various fractions, proteins were analyzed by a classical $12 \%$ or $18 \%$ SDS-PAGE. $5 \mu$ of samples were mixed with $10 \mu$ of sample buffer (Laemmli Sample Buffer, Bio-Rad) and put in electrophorese at 200mV, 15-20mA for $2 \mathrm{~h}$. Proteins are visualized by silver staining of the gel.

Sample preparation for mass spectrometry: Active fractions containing minima of protein were gathered together, 10x concentrated by ultracentrifugation (Amicon) and rid of $\mathrm{NaCl}$ by dialysis (Spectra/Por Dialysis Membrane, cutoff 12-14kDa, Spectrum) four times against a Tris- $\mathrm{HCl}$ buffer $25 \mathrm{mM}, \mathrm{pH} 7.2$ for $48 \mathrm{~h}$ at $4^{\circ} \mathrm{C}$. After dialysis, the sample was concentrated by lyophilisation to $100 \mu$, to which $10 \mu \mathrm{l}$ DTT $500 \mathrm{mM}$ was added in $\mathrm{NH}_{4} \mathrm{HCO}_{3}$ $25 \mathrm{mM}$ for $2 \mathrm{~h}$ at $60^{\circ} \mathrm{C}$. Proteins were then alkylated with iodoacetamide $500 \mathrm{mM}$ in $\mathrm{NH}_{4} \mathrm{HCO}_{3}$ 
$25 \mathrm{mM}$ for $1 \mathrm{~h}$ at room temperature. Trypsin solution (1/500) was added to the sample and incubated at $37^{\circ} \mathrm{C}$ for $3 \mathrm{~h}$. After solvent evaporation in SpeedVac, tryptic peptides were analyzed using spectrometry. Each step of the sample preparation such as dialysis or concentration, sample activity was checked on sea cucumber oocytes.

Mass Spectrometry: The tryptic peptides were analyzed with nanoLC-MS/MS using an LC Ultimate 3000 system (Dionex) coupled to an HCTultra plus mass spectrometer (Bruker). Dried peptides were reconstituted in $8 \mu \mathrm{L}$ of loading solvent (acetonitrile 5\%, trifluoroacetic acid $0.025 \%$ in HPLC-grade water) and $6 \mu \mathrm{L}$ were loaded onto a precolumn (C18 Trap, $300 \mu \mathrm{m}$ ID x $5 \mathrm{~mm}$, Dionex) using the ultimate 3000 system, delivering a flow rate of $20 \mu \mathrm{L} / \mathrm{min}$ of loading solvent. After desalting for $10 \mathrm{~min}$, the precolumn was switched online with the analytical column (75 $\mu \mathrm{m}$ ID x $15 \mathrm{~cm}$ PepMap C18, Dionex) equilibrated in 96\% solvent A (formic acid $0.1 \%$ in HPLC-grade water) and $4 \%$ solvent B (acetonitrile $80 \%$, formic acid $0.1 \%$ in HPLC-grade water). The peptides were eluted from the precolumn to the analytical column and then to the mass spectrometer with a gradient from 4 to $57 \%$ solvent $\mathrm{B}$ for $35 \mathrm{~min}$ and 57 to $90 \%$ solvent $\mathrm{B}$ for $10 \mathrm{~min}$, at a flow rate of $300 \mathrm{~nL} / \mathrm{min}$ delivered by the Ultimate pump. The peptides were analyzed using the "peptide scan" option of the HCT Ultra Ion Trap (Bruker), consisting of a full-scan MS and MS/MS scan spectrum acquisitions in ultrascan mode $\left(26^{\prime} 000 \mathrm{~m} / \mathrm{z} / \mathrm{s}\right)$. Peptide fragment mass spectra were acquired in datadependent Auto MS (2) mode with a scan range of 100 to $2800 \mathrm{~m} / \mathrm{z}$, three averages, and 5 precursor ions selected from the MS scan from 300 to $1500 \mathrm{~m} / \mathrm{z}$. Precursors were actively excluded within a 0.5 minute window, and all singly charged ions were excluded. The peptide peaks were detected and deconvoluted automatically using Data Analysis 2.4 software (Bruker). Mass lists in the form of Mascot Generic Files were created automatically and used as the input for Mascot MS/MS Ion searches of the NCBInr database release 20080704 using an in-house Mascot 2.2 server (Matrix Science). The default search parameters used were: taxonomy $=$ all species, enzyme $=$ trypsin, maximum missed cleavages $=1$, fixed modification $=$ Carbamidomethyl $(\mathrm{C})$, variable modification $=$ Oxidation $(\mathrm{M})$, peptide mass tolerance $\pm 1.5 \mathrm{Da}$, fragment mass tolerance $\pm 0.5 \mathrm{Da}$, peptide charge $=1+, 2+$ and $3+$; instrument $=$ ESI-TRAP. Only sequences identified with a Mascot score of at least 50 were considered. For each protein identified from one single peptide, MS/MS spectra were evaluated manually.

Three proteins identified in REES by spectrometry (toposome, ubiquitin and thioredoxin) were tested for oocyte maturation. Purified toposome from Tripneustes gratilla 
was obtained from Professor M. Nolls at the Institute for Molecular Biology, University of Zürich, (Switzerland) (Noll et al., 1985). Ubiquitin from bovine erythrocyte (U6253) and thioredoxin from Escherichia coli (T0910) were purchased from Sigma-Aldrich.

\section{Anti-Thioredoxin antibody}

The active fraction of REES $(115 \mu \mathrm{l})$, from which thioredoxin (Trx, hereafter) was

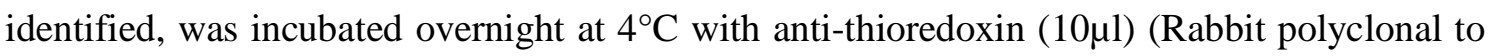
Trx-2 (ab16836), antibody, Abcam) to block Trx activity. The active fraction of REES was also incubated in the same conditions $\left(125 \mu \mathrm{l}\right.$, overnight at $\left.4^{\circ} \mathrm{C}\right)$ but without anti-thioredoxin, to ensure that the capacity to induce oocyte maturation was not altered by the experimental conditions. After incubation, a volume of $125 \mu 1$ of oocytes was added to these both solutions. Anti-thioredoxin $(10 \mu \mathrm{l})$ was also tested alone on oocytes $(240 \mu \mathrm{l})$ to check eventual damage on oocytes by this antibody. The maturation of oocytes was monitored by observing the germinal vesicle breakdown (GVBD) and the formation of polar bodies with a light microscope after an incubation time of $2 \mathrm{~h}$ at $21^{\circ} \mathrm{C}$.

\section{Immuno Blot analysis}

Commercial Trx from E. coli (Sigma-Aldrich) and the purified fraction of REES inducing oocyte maturation were separated by $18 \%$ SDS-PAGE and blotted on a PVDF membrane (Bio-Rad) for $40 \mathrm{~min}$ at $500 \mathrm{~mA}$ and $25 \mathrm{~V}$. The membrane was then washed three times for $5 \mathrm{~min}$ in $25 \mathrm{mM}$ TBS (Tris-HCl buffer 25mM, pH 7.2, $\mathrm{NaCl} 125 \mathrm{mM}$ ), $0.05 \%$ (v/v) Tween 20 (Immunoblot Buffer (IB)). IB containing 5\% (w/v) milk powder (blocking solution) was then added for $1 \mathrm{~h} 30$ at $20^{\circ} \mathrm{C}$. The membrane was incubated overnight at $4^{\circ} \mathrm{C}$ with primary antiserum (1:200, Rabbit polyclonal to Trx-2, antibody, Abcam) diluted in immunoblotting buffer containing $1.25 \%(\mathrm{w} / \mathrm{v})$ milk powder. The membrane was rinsed in IB (5x5 $\mathrm{min})$ before incubation with the secondary antibody (1:5000, goat anti-rabbit, horseradish peroxidase-conjugated; Pierce) diluted in IB, $1.25 \%(\mathrm{w} / \mathrm{v})$ milk powder. Immunoreactive proteins were detected using a chemiluminescence detection kit (Lumilight Western Blotting substrate; Roche Applied Science) following the instructions of the manufacturer. 
The catalytic site of the Trx of Strongylocentrotus purpuratus was identified with homology-based search using BLAST tool. A 6 AAs peptide (WCNPCK, Trp-Cys-Asn-ProCys-Lys) - named Trx-6AAs - was synthetised by GenScript (USA). We then tested the effect of Trx-6AAs on the oocyte maturation of Holothuria scabra. Trx-6AA was first dissolved in $0.22 \mu \mathrm{m}$-filtered seawater to reach concentrations of $0.06,0.1,0.12,0.2$ and $0.25 \mathrm{mg} \mathrm{ml}^{-1}$. The oocyte maturation was assessed with the observation of the vesicle breakdown (GVBD) and the formation of polar bodies, as previously detailed, after an incubation time of $2 \mathrm{~h}$. The portion of mature oocytes was determined by randomly counting 100 oocytes per sample allowing the MI calculation. For each concentration, oocytes from three holothuroids were used. For each biological replicate, two controls were performed using the same incubation time: a positive control that consists in incubating oocytes in a REES solution $\left(2 \mathrm{mg} \mathrm{ml}^{-1}\right)$ and a negative control where oocytes were placed in seawater.

\section{Results}

The effect of oocyte incubation in various concentrations of the REES solution is reported on the Figure 1. At a concentration of 0.2 to $2 \mathrm{mg} \mathrm{ml}^{-1}$ of REES in filtered seawater, the maturation index of $H$. scabra oocytes reaches 98. At concentrations lower than $0.1 \mathrm{mg}$ $\mathrm{ml}^{-1}$ or higher than $4 \mathrm{mg} \mathrm{ml}^{-1}$, REES is less effective for inducing oocyte maturation. The fertilisation curve followe the maturation curve and $98 \%$ of mature oocytes undergo fertilisation. Based on these results, we used concentration of $2 \mathrm{mg} \mathrm{ml}^{-1}$ of REES for all subsequent experiments.

The treatment of REES by proteinase $\mathrm{K}$ induces the loss of maturation-inducing effect. It demonstrates that the compound(s) allowing maturation is of proteinic nature (Figure 2). When oocytes are incubated in proteolysed REES, the MI is less than 18.1 for $H$. scabra and 37.3 for H. tubulosa, which is close to the MI in seawater (22.8 for H. scabra and 46.88 for $H$. tubulosa) (Figure 2). At the opposite, the MI of non-proteolysed REES is of 100. An average MI of 76.9 for H. scabra and 87.9 for H. tubulosa is observed in the control (i.e., when oocytes is incubated in REES that had undergone the same treatment as proteolysed REES but without the addition of proteinase K) (Figure 2).

Figure 3 illustrates the maturation performances of dialysed or non-dialysed REES. After dialysis with a dialysis membrane characterised by a cutoff of $12-14 \mathrm{kDa}$, the samples were tested on holothuroids oocytes (Figure 3). The average MI is of 97.8 for oocytes placed 
in presence of dialysed REES (96.3 for H. scabra and 99.3 for H. tubulosa) (Figure 3). The MI for oocytes in seawater is about 23.4 for H. scabra and 32.3 for H. tubulosa (Figure 3). This experiment suggests that the active molecule in purified REES fraction has an apparent molecular weight greater than $12 \mathrm{kDa}$.

REES samples were then fractioned using a Sephadex G-100 non-denaturating chromatography. The elution profile of REES at $280 \mathrm{~nm}$ showed the presence of two major absorbance peaks, the first goes from fractions 33 to 56 and the second from 93 to 115 (Figure 4). Protein analysis by $12 \%$ SDS-PAGE showed that high molecular weights of 50 to $200 \mathrm{kDa}$ were concentrated in fractions corresponding to the first peak, while the second absorbance peak was essentially made of small proteins-peptides and amino acids. Interestingly, only 27 fractions among 160 (61-88) of the REES extract were able to induce sea cucumber oocyte maturation (Figure 4). These 27 fractions were successive and situated between the major two absorbance peaks (Figure 4). When oocytes are incubated in one of these 27 fractions, the maturation rate was between $66 \%$ and $99 \%$ (Figure 4). For oocytes incubated in the other fractions, the maturation rate was less than $53 \%$ and often relatively close to the rate of spontaneous maturation (21\%). The maximum of maturation (between $92 \%$ and $99 \%$ of maturation) were obtained with the $71^{\text {th }}$ at $86^{\text {th }}$ fractions (Figure 4). These most active fractions were gathered into 3 active samples (A: fractions 71-75, B: fractions 76-80 and C: fractions 81-86) containing sufficient amounts of proteins to perform mass spectrometry analyses (sample A: $0.388 \mu \mathrm{g} / \mu 1$, sample B: $0.073 \mu \mathrm{g} / \mu 1$, sample C: $0.060 \mu \mathrm{g} / \mu \mathrm{l}$ ) (Figure 5). SDS-PAGE of these 3 active samples showed that they were constituted of some proteins (Figure 5). For the following step, we focused on the sample $\mathrm{C}$ because of the lower protein complexity.

To identify the maturation-inducing protein, active sample $\mathrm{C}$ was then analysed using mass spectrometry. As showed in Table 1, seven different proteins were identified from sample C: (i) Toposome (Tripneustes gratilla), (ii) Actin (Strongylocentrotus purpuratus and Lytechinus variegatus), (iii) Protein similar to fibrillin-3 (Strongylocentrotus purpuratus), (iv) Hypothetical protein isoform 3 (Strongylocentrotus purpuratus), (v) Protein similar to ubiquitin (Strongylocentrotus purpuratus), (vi) Protein similar to epidermal growth factor II precursor (Strongylocentrotus purpuratus) and (vii) Hypothetical protein from Strongylocentrotus purpuratus.

Blast similarity against NCBI database revealed that the "hypothetical protein isoform 3" belongs to the Trx family. The Figure 6 shows the alignment with the Trx of the closest 
sequences retrieved in BLAST. For the last protein identified as similar to a "hypothetical protein" from Strongylocentrotus purpuratus, any information about function similarity, activity and structural domain was obtained.

In the aim to identify the protein allowing the oocyte maturation, three of these identified proteins have been tested. Purified ubiquitin (from bovine erythrocyte), toposome (from T. gratilla) and Trx (from E. coli) were tested at a concentration of 0.01 to $0.12 \mathrm{mg} \mathrm{ml}^{-1}$ in a Tris- $\mathrm{HCl}$ buffer $25 \mathrm{mM}, \mathrm{pH} 7.2$. These concentrations were similar to those of the active fraction from which these proteins were isolated $\left(0.060 \mathrm{mg}\right.$ of protein $\left.\mathrm{ml}^{-1}\right)$. At the opposite of Trx, no significant statistical difference was observed between the MI in seawater (25.7), ubiquitin (21.1) and toposome (27.0) for each tested concentrations (Figure 7 and Figure 8). Clearly, Trx gives an MI (83.8) similar to that of REES (100) at a concentration of $0.12 \mathrm{mg}$ $\mathrm{ml}^{-1}$ (Figure 9).

To validate our proteomics studies, we confirmed the maturation-inducing properties of Trx-REES using anti-thioredoxin antibodies to block REES activity. In this context, the active fraction, from which Trx was identified, was then incubated overnight with antithioredoxin antibodies. Tested alone, anti-thioredoxin antibodies did not cause any damage to oocytes nor to their maturation (MI=24.7) (Figure 10). The active fraction pre-incubated overnight with anti-thioredoxin antibodies yielded a MI of 20.7, which was not significantly different from the MI in sea water (9.1) (Figure 10). In contrast, active fraction incubated in the same conditions without anti-thioredoxin yielded a MI of 105.0, a value similar to the one defined for REES (100) (Figure 10). The presence of a Trx in REES was confirmed by immunoblot analysis using an anti-thioredoxin antibody. As showed in the Figure 11, only one protein band of $18 \mathrm{kDa}$ was visualised from REES thanks to anti-thioredoxin antibody.

The Figure 12 shows the results obtained when oocytes of $H$. scabra are incubated in solutions containing the Trx-6AAs peptide corresponding to the catalytic site of the Trx of Strongylocentrotus purpuratus (WCNPCK). The graph illustrates the MI measured on oocytes of 3 individuals for 5 concentrations of Trx-6AAs. This test was performed at the beginning of the reproductive period of $H$. scabra reproduction in Madagascar (December). A portion of oocytes placed in seawater was already at maturity indicating that the holothuroids were ready to breed. This proportion varied from 17 to $44 \%$ of the total number of oocytes in the ovary. The incubation in REES always boosted the maturation and the mature oocytes were, in average, 1.7 times more important than the negative control after $2 \mathrm{~h}$ of incubation. The incubation in Trx-6AAs was significantly more effective than the incubation in seawater for the concentrations $0.2,0.25$ and $0.3 \mathrm{mg} \mathrm{ml}^{-1}$. The 
incubation in Trx-6AAs was also significantly more effective than the incubation for the concentration of $0.2 \mathrm{mg} \mathrm{ml}^{-1}$.

\section{Discussion}

Incubation in sea urchin spawn extract effectively induces GVBD of aspidochirote holothuroids including H. scabra and H. tubulosa oocytes (Léonet et al., 2009). Experiments carried out in the present study have first shown that the agent inducing holothuroid oocyte maturation is a protein with a molecular weight greater than $12 \mathrm{kDa}$. Fractionation of REES using exclusion chromatography enables us to obtain an active fraction that contains seven proteins identified by nanoLC-MS/MS. The proteins were: $(i)$ toposome [a modified iron-less calcium-binding transferring that acts in cell adhesion and development], (ii) actin and (iii) fibrillin-3 [two structural proteins], (iv) a hypothetical protein isoform 3 (Strongylocentrotus purpuratus), ( $v)$ a protein similar to ubiquitin [that acts on a large range of target proteins for labeling them for proteasomal degradation. Besides this function, ubiquitination also controls the stability, function, and intracellular localisation of a wide variety of proteins], (vi) a protein similar to epidermal growth factor II precursor and (vii) a hypothetical protein from Strongylocentrotus purpuratus. Among these 7 proteins, structural proteins essential in oocytes cannot be agents inducing holothuroid oocyte maturation. If it was the case, maturation should also be induced by oocytes of sea stars, of sea cucumbers or of irregular sea urchins but that is not the case (see Léonet et al., 2009): only regular sea urchin spawns are able to induce sea cucumber oocyte maturation. We have been able to test the effect of three of the five other possible candidates: ubiquitin, toposome and the hypothetical protein isoform 3 identified as a new Trx close to Trx-2 to which we give the name REES. Commercial Trx from E. coli, was able to induce oocyte maturation with a MI similar to the ones obtained when we used REES. Furthermore, addition of anti-thioredoxin antibody to the active fraction causes the loss of its effect. Yet, anti-thioredoxin used in immunoblot prominently displayed a protein in the active fraction, a protein with a molecular weight of approximately $18 \mathrm{kDa}$ - the same molecular weight as "hypothetical protein isoform" (18.7 kDa). The other protein highlighted by immunoblot was the Trx from E. coli, a Trx-1 that has a molecular weight of $11.7 \mathrm{kDa}$. Surprisingly, in Léonet et al. (2009), we observed that the spawns of sea cucumbers do not induce the maturation of sea cucumber oocytes as the spawns in regular echinoids do. It could indicate that the concentration of Trx in sea cucumber spawns is not always adequate 
to induce the maturation.

Trxs are small and multi-functional proteins. There are ubiquitous proteins containing a conserved Cys-Gly-Pro-Cys redox catalytic site that undergoes reversible oxidation to cysteine-disulfide bridge through the transfer of reducing agents to a disulfide substrate (Holmgren, 1985; Holmgren, 1989; Luthman and Holmgren, 1982). We here demonstrated that the synthetic catalytic site of the Trx, WCNPCK, induced the oocyte maturation of holothuroids. Trx family members include Trx-1 (12000Da), Trx-2 (18000Da), and Trx-like proteins (Powis et al., 2000). Trxs act as growth factors (Wakasugi et al., 1987; Wakasugi et al., 1990), antioxidants (Spector et al., 1988; Bjornstedt et al., 1994), cofactors (Laurent et al., 1964; Hopper et al., 1983) and in the regulation of transcription factors (Gilmore et al., 1997; Hayashi et al., 1993). Trd prevents apoptosis (Baker et al., 1997) and contributes to increased resistance to chemotherapy in human cancer (Kunkel et al., 1997). Trx is widely distributed in various organisms including prokaryotes and eukaryotes and is expressed during human fetal development (Fujii et al., 1991) which is not surprisingly, given its role in controlling cell growth (Matsui et al., 1996). The reduction of the disulfide bond of the catalytic site in oxidised Trx is catalysed by Trx-reductase with NADPH-dependent flavoprotein thioredoxin reductase as the electron donor (Powis et al., 2000).

Amongst the various functions of Trx, some deal with cell division and meiosis in particular. Natsuyama et al. (1993) showed that exogenous Trx released mouse embryos from mitotic block when they are arrested at the second stage (Natsuyama et al., 1993). Trx has been shown to prevent the inhibition of cdc25 phosphatase activity, which leads to impairment of $\mathrm{p} 34^{\mathrm{cdc} 2}$ dephosphorylation during the second cell cycle of mouse embryonic development in vitro (Natsuyama et al., 1993). It has been suggested that the Trx effects are due to its action as an antioxidant by protecting against oxygen species, because superoxide dismutase also prevented the inhibition of cdc25 phosphatase activity (Natsuyama et al., 1993; Powis et al., 2000). It is probable that Trx-REES releases meiotic block in unfertilised sea cucumber oocytes in a similar way than the Trx release of mitotic block in mouse embryos (Natsuyama et al., 1993). Nevertheless, p34 ${ }^{\text {cdc2 }}$ is the constituent of MPF (Maturation-Promoting Factor), a universal factor permitting cells to enter into mitosis and meiosis (Dunphy et al., 1988; Lohka et al., 1988, Labbe et al., 1989). During meiosis or mitosis the activation mode of MPF is the same for many organisms (Hoffman et al., 1993; Choi et al., 1991), we can thus presume that Trx probably acts in the same way for sea cucumber oocytes as for mouse embryos. It was questionable whether exogenous Trx restored $\operatorname{cdc} 25$ and/or $\mathrm{p} 34^{\text {cdc2 }}$ activities by direct interaction with these cellular proteins, whereas $\operatorname{Trx}$ 
binds to the cell surface and was not taken up by the cell (Gasdaska et al., 1995). Exogenous Trx may thus act as a general extracellular antioxidant rather than specifically restoring the activity of intracellular $\mathrm{p} 34^{\mathrm{cdc} 2}$ and $\operatorname{cdc} 25$ (Vogt et al., 2000).

In conclusion, we demonstrated that thioredoxins induce maturation of oocytes in two sea cucumber species and we identified the active site of the protein (i.e. WCNPCK). As this site is a redox catalytic site, thioredoxins potentially induce oocyte maturation in acting on the redox potential. Whether the action of thioredoxins is a natural process occurring in holothuroids is presently uncertain but some of the molecules that influence the redox potential like thioredoxins may be useful in the aquaculture of holothuroids: they open a new way to obtain embryos in sea cucumber hatchery, the in vitro fertilisation, which is more reliable than the classical spawning induction method (Eeckhaut et al., 2012).

\section{References}

1. Baker, A., Payne, C.M., Briehl, M.M., Pwis, G., 1997. Thioredoxin a gene found overexpressed in human cancer, inhibits apoptosis in vitro and in vivo. Cancer Res. 57, 5162-5167.

2. Bjornstedt, M., Xue, J., Huang, W., Akesson, B., Holmgren, A., 1994. The thioredoxin and glutaredoxin systems are efficient electron donors to human plasma glutathione peroxidase. J. Biol. Chem. 269, 29382-29384.

3. Chen, C.P., Hsu, H.W., Deng, D.C., 1991. Comparison of larval development and growth of sea cucumber Actinopyga echinites: ovary-induced ova and DTT-induced ova. Mar. Biol. 109, 453-457.

4. Choi, T., Aoki, F., Mori, M., Yamashita, M., Nagahama, Y., Kohmoto, K., 1991. Activation of $\mathrm{p} 34^{\mathrm{cdc} 2}$ protein kinase activity in meiotic and mitotic cell cycles in mouse oocytes and embryos. Development 113, 789-795.

5. Costello, D., Davidson, M.E., Eggers, A., Fox, M.H., Henley, C., 1957.

Echinodermata (Holothuroidea). In: Methods for Obtaining and Handling Marine Eggs and Embryos. Marine Biological Laboratory, Woods Hole, Massechusetts, $247 \mathrm{pp}$.

6. Dunphy, W.G., Brizuela, L., Beach, D., Newport, J., 1988. The Xenopus cdc2 protein is a component of MPF, a cytoplasmic regulator of mitosis. Cell 56, 829-838. 
7. Eeckhaut, I., Lavitra, T., Léonet, A., Jangoux, M., Rasolofonirina, R., 2012. In-vitro fertilisation : a simple, efficient method for obtaining sea cucumber larvae year round. Hair C.A., Pickering T.D. and Mills D.J. (eds) 2012. ACIAR Proceedings No. 136. Australian Centre for International Agricultural Research: Canberra, pp 40-49.

8. Fujii, S., Nanbu, Y., Konishi, I., Mori, T., Masutani, H., Yodoi, J., 1991. Immunohistochemical localisation of adult T-cell leukaemia derived factor, a human thioredoxin homologue, in human fotal tissues. Virchows Arch. A Pathol. Anat. Histopathol. 419, 317-326.

9. Fujiwara, A., Yamano, K., Ohno, K., Yoshikuni, M., 2010. Spawning induced by Cubifrin in the Japanese common sea cucumber, Apostichopus japonicus. Fisheries Sci. 76: 795-801

10. Gasdaska, J.R., Berggren, M., Powis, G. 1995. Cell growth stimulation by the redox protein thioredoxin occurs by novel helper mechanism. Cell Growth Differ. 6, 16431650.

11. Gilmore, T.D., Koedood, M., Piffat, K.A., White, D.W., 1997. Rel/NF-кB/IкB proteins and cancer. Oncogene 11, 1367-1378.

12. Hayashi, T., Ueno, Y., Okamoto, T., 1993. Oxidoreductive regulation of nuclear factor кB: involvement of a cellular reducing catalyst thioredoxin. J. Biol. Chem. 268, 11380-11388.

13. Hoffmann, I., Clarke, P.R., Marcote, M.J., Karsenti, E., Draetta, G., 1993. Phosphorylation and activation of human cdc25-C by cdc2-cyclin B and its involvement in the self-amplification of MPF at mitosis. EMBO J. 12, 53-63.

14. Holland, N.D., 1991. Echinoderme: Crinoïdea. In: Giese, Pearse, and Pearse, (eds). Reproduction of marine invertebrates. The Boxwood Press, California, pp 247-299.

15. Holmgren, A., 1985. Thioredoxin. Annu. Rev. Biochem. 54, 237-271.

16. Holmgren, A., 1989. Thioredoxin and glutaredoxin systems. J. Biol. Chem. 264, 13963-13989.

17. Hopper, S., Iurlano, D., 1983. Properties of thioredoxin purified from rabbit bone marrow which fails to serve as a hydrogen donor for the homologous ribonucleotide reductase. J. Biol. Chem. 258, 13453-13457.

18. Hufty, H.M., Schroeber, P.C., 1974. A hormonally active substance produced by ovary of the holothurian Parastichopus californicus. Gen. Comp. Endocrinol. 23, 348351.

19. Ikegami, S., Kanatani, H., Koide, S.S., 1976. Gamete release in vitro in the sea 
cucumber Leptosynapta inhaerens. Biol. Bull. 150, 402-410.

20. Kanatani, H., 1974. Presence of 1-Methyladenine in sea urchin gonad and its relation to oocyte maturation. Dev. Growth Differ. 16, 159-170.

21. Kato, S., Tsurumaru, S., Taga, M., Yamane, T., Shibata, Y., Ohno, K., Fujiwara, A., Yamano, K., Yoshikuni, M., 2009. Neuronal peptides induce oocyte maturation and gamete spawning of sea cucumber, Apostichopus japonicus. Dev. Biol. 326, 169-176.

22. Katow, H., Katow, T., Moriyama, A., 2009. Gonad stimulating substance-like molecule from the radial nerve of the sea cucumber. Int. J. Dev. Biol. 53: 483-491.

23. Kishimoto, T., Kanatani, H., 1973. Induction of starfish oocyte maturation by disulfide- reducting agents. Exp. Cell Res. 82, 296-302.

24. Kishimoto, T., Kanatani, H., 1980. Induction of oocyte maturation by disulfidesreducing agent in the sea cucumber, Stichopus japonicus. Dev. Growth Differ. 22, 163-167.

25. Kishimoto, T., Cayer, M.L., Kanatani. H., 1976. Starfish oocyte maturation and reduction of disulfide- bond on oocyte surface. Exp. Cell Res. 101, 104-110.

26. Kishimoto, T., Kuriyama, R., Kondo, H., Kanatani, H., 1982. Generality of the action of various maturation- promoting factors. Exp. Cell Res. 137, 121-126.

27. Kunkel, M.W., Kirkpatrick, D., Johnson, J.I., Powis, G., 1997. Cell line-directed screening assay for inhibitors of thioredoxin reductase signalling as a potential anticancer drugs. Anticancer Drug Des. 12, 659-670.

28. Labbe, J.C., Picard, A., Peaucellier, G., Cavadore, J.C., Nurse, P., Doree, M., 1989. Purification of MPF from starfish: Identification of the $\mathrm{H} 1$ histone kinase $\mathrm{P}^{34 \mathrm{cdc} 2}$ and a possible mechanism for its periodic activation. Cell 57, 253-263.

29. Laurent, T.C., Moore, E.C., Reichard, P., 1964. Enzymatic synthesis of deoxyribonucleotidesVI. Isolation and characterization of thioredoxin, the hydrogen donor from Escherichia coli B. J. Biol. Chem. 239, 3436-3444.

30. Léonet, A., Rasolofonirina, R., Wattiez, R., Jangoux, M., Eeckhaut, I., 2009. A new method to induce oocyte maturation in holothuroids (Echinodermata). Inv. Rep. Dev. $53,13-21$.

31. Lohka, M.J., Hayes, M.K., Malder, J.L., 1988. Purification of maturation-promoting factor, an intracellular regulator of early mitotic events. Proc. Natl. Acad. Sci. U.S.A. 85, 3009-3013.

32. Luthman, M., Holmgren, A., 1982. Rat liver thioredoxin reductase: purification and characterization. Biochemistry 21, 6628-6633. 
33. Maruyama, Y.K., 1980. Artificial induction of oocyte maturation and development in sea cucumbers Holothuria leucospilota and Holothuria pardalis. Biol. Bull., 158, 339348.

34. Maruyama, Y.K., 1985. Holothurian oocyte maturation induced by radial nerve. Biol. Bull. 168, 249-262.

35. Matsui, M., Oshima, M., Oshima, H., Takaku, K., Maruyama, T., Yodoi, J., Taketo, M. M., 1996. Early embryonic lethality caused by targeted distruption of mouse thioredoxin gene. Dev. Biol. 178:179-185.

36. Mc Euen, F.C., 1988. Spawning behaviors of northeast Pacific sea cucumbers (Holothuroidea: Echinodermata). Mar. Biol. 98, 565-585.

37. Natsuyama. S., Noda, Y., Yamashita, M., Nagahama, Y., Mori, T., 1993. Superoxide dismutase and thioredoxin restore defective p34 cdc2 kinase activation in mouse twocell block. Biochim. Biophys. Acta. 1176, 90-94

38. Noll, H., Matranga, V., Cervello, M., Humphreys, T., Kuwasaki, B., Adelson, D., 1985. Characterization of toposomes from sea urchin blastula cells: A cell organelle mediating cell adhesion and expressing positional information. Proc. Natl Acad. Sci. USA 82, 8062-8066.

39. Pearse, J.S., Cameron, R.A., 1991. Echinoderme: Echinoidea. In: Giese, A.C., Pearse, J.S. and Pearse, V.B., (eds). Reproduction of marine invertebrates, 6, The Boxwood Press, California, pp 513-662.

40. Powis, G., Mustacich, D., Coon, A., 2000. The role of the redox protein thioredoxin in cell growth and cancer. Free Radical Bio. Med. 29, 312-322.

41. Rasolofonirina, R., Vaïtillingon, D., Eeckhaut, I., Jangoux, M., 2005. Reproductive cycle of edible echinoderms from the southwestern Indian Ocean. Western Indian Ocean J. Mar. Sci. 4, 61-75.

42. Suwansa-ard, S., Chaiyamoon, A., Talarovicova, A., Tinikul, R., Tinikul, Y., Poomtong, T., Elphick, M. R., Cummins S. F. \& Sobhon, P., 2018. Transcriptomic discovery and comparative analysis of neuropeptide precursors in sea cucumbers (Holothuroidea). Peptides. 99, 231-240.

43. Smiley, S., 1990. A review of echinoderm oogenesis. J. Electron Microsc. 16, 93-114.

44. Smiley, S., 1988. Investigations into the purification and identification of the oocyte maturation hormone of the sea cucumber Stichopus califiornicus. In: Echinoderm Conference in Victoria B.C., eds: R.D. Burke, et al., Balkema Press, Rotterdam.

45. Spector, A., Yan, G.Z., Huang, R.R. C., McDermott, M.J., Gascoyne, P.R. C., Pigiet, 
V., 1988. The effect of $\mathrm{H}_{2} \mathrm{O}_{2}$ upon thioredoxin-enriched lens epithelial cells. J. Biol. Chem. 263, 4984-4990.

46. Vogt, A., Tamura, K., Watson, S., Lazo, J., S., 2000. Antitumor imidazolyl disulfide IV-2 causes irreversible G2/M cell cycle arrest without hyperphosphorylation of cyclin-dependent kinase Cdk1. J. Pharmacol. Exp. Ther. 294, 1070-1075.

47. Wakasugi, H., Rimski, L., Mathe, Y., Kamel, A.M., Fradelizi, D., Tursz, T., Bertogio, J., 1987. Epstein-Barr virus-containing B-cell line produces and interleukin 1 that it uses as a growth factor. Proc. Natl. Acad. Sci. USA 84, 804-808.

48. Wakasugi, N., Tagaya, Y., Wakasugi, A., Mitsui, M., Maeda, M., Yodoi, J., Tursz, T., 1990. Adult T-cell leukaemia-derived factor/thioredoxin produced by both human Tlymphotropic virus type 1 and Epstein-Barr virus-transformed lymphocytes, acts as an autocrine growth factor and synergized with interleukin-1 and interleukin-2. Proc. Natl. Acad. Sci. USA 87, 8282-8286.

49. Zandawala, M., Moghul, I., Guerra, L. A. Y., Delroisse, J., Abylkassimova, N., Hugall, A. F., O'hara, T.D. \& Elphick, M. R., 2017. Discovery of novel representatives of bilaterian neuropeptide families and reconstruction of neuropeptide precursor evolution in ophiuroid echinoderms. Open biology, 7(9), 170129.

\section{Acknowledgements:}

We are very grateful to Professor M. Noll for sending us a purified sample of toposome. We thank to Mrs. Shelby, for English correcting of this manuscript. Aline Léonet was supported by a F.R.I.A. grant (Belgium). Jérôme Delroisse is supported by a WISD-PDR grant from the National Funds for Research (FNRS-F.R.S. Belgium, Project number 29101409). The project research was supported by a "Projet Interuniversitaire Ciblé" (PIC) funded by the Belgian "Commission Universitaire au Développement" (CUD). 


\section{Figure captions}

Figure 1. Oocyte maturation index (full line) and percentage of oocyte fertilisation (dotted line) rates in Holothuria scabra according to the concentration of REES. Values are means \pm S.D. ( $\mathrm{n}=3$ individuals $)$.

Figure 2. Effect of the proteinase $\mathrm{K}$ on the REES. The REES control test was conducted using REES in the same conditions than proteolysed REES without proteinase K. Values are means of Maturation index \pm S.D. ( $n=3$ individuals). The bar above the columns indicates that there was no significant difference between the results obtained for $H$. scabra and $H$. tubulosa. Means sharing at least one letter are not significantly different $\left(\mathrm{T}_{\text {Tukey }} \geq 0.05\right)$.

Figure 3. Maturation indexes of $H$. scabra and $H$. tubulosa oocytes incubated in dialysed REES, in REES or in seawater. Values are means of Maturation index \pm S.D. $(n=3$ individuals). The bar above the columns indicates that was no significant difference between the results obtained for $H$. scabra and H. tubulosa. Means sharing at least one letter are not significantly different $\left(\mathrm{T}_{\text {Tukey }} \geq 0.05\right)$.

Figure 4. Absorbance at 280nm (full line) and biological activity (dotted line) of REES fractions obtained by exclusion chromatography (Sephadex G100). REES activity was expressed in terms of percentage of GVBD.

Figure 5. SDS-PAGE (18\%) of (A) active REES pooled fractions 71 to 75, (B) 76 to 80 and (C) 81 to 86 obtained by Sephadex G-100 exclusion chromatography. MW: Molecular weight standard (Precision Plus Protein All Blue Standards, Bio-rad). Proteins were visualised by silver staining.

Figure 6. Identification of the "hypothetical protein isoform 3" as a member of the Trx family. Alignment of the predicted amino acid sequence of Strongylocentrotus purpuratus Trx-2 (gb/XP_790171) with Trx-like of Apostichopus japonicas (gb/PIK46969.1), Trx of Salmo salar (gb/XP_014059051), Trx-2 of Xenopus laevis (gb/AAH43794), Trx-2 of Haliotis discus discus (gb/ABO26636) and Trx of Escherichia coli (gb/AAA24693). Conserved amino 
acids conserved in all sequences are highlighted in colour. The catalytic site of thioredoxins is framed in black.

Figure 7. Maturation indexes of $H$. tubulosa oocytes incubated in ubiquitin with concentrations of 0.01 to $0.12 \mathrm{mg} \mathrm{ml}^{-1}$. Values are means of Maturation index \pm S.D. $(\mathrm{n}=3$ individuals). Means sharing at least one letter are not significantly different $\left(\mathrm{T}_{\text {Tukey }} \geq 0.05\right)$.

Figure 8. Maturation indexes of $H$. tubulosa oocytes incubated in toposome with a concentration of 0.01 to $0.12 \mathrm{mg} \mathrm{ml}^{-1}$. Values are means of Maturation index \pm S.D. ( $\mathrm{n}=2$ individuals). Means sharing at least one letter are not significantly different $\left(\mathrm{T}_{\text {Tukey }} \geq 0.05\right)$.

Figure 9. Maturation indexes of $H$. tubulosa oocytes incubated in Trx from E. coli with a concentration of 0.01 to $0.12 \mathrm{mg} \mathrm{ml}^{-1}$. Values are means of Maturation index \pm S.D. $(\mathrm{n}=4$ individuals). Means sharing at least one letter are not significantly different $\left(\mathrm{T}_{\text {Tukey }} \geq 0.05\right)$.

Figure 10. Maturation indexes of $H$. tubulosa oocytes incubated in active fraction of REES incubated overnight with anti-thioredoxin to block REES activity. Values are means of Maturation index \pm S.D. ( $\mathrm{n}=2$ individuals). Means sharing at least one letter are not significantly different $\left(\mathrm{T}_{\text {Tukey }} \geq 0.05\right)$.

Figure 11. Active fraction of REES and commercial Trx from E. coli compared by $18 \%$ SDSPAGE (silver staining) and by immunoblot with anti-thioredoxin (Rabbit polyclonal to Trx-2, antibody, Abcam). MW: Molecular weight standard (Precision Plus Protein All Blue Standards (Bio-rad).

Figure 12. Maturation indexes of $H$. scabra oocytes incubated in trx-6AAs with a concentration of 0.06 to $0.3 \mathrm{mg} \mathrm{ml}^{-1}$. Values are means of Maturation index \pm S.D. $(n=3$ individuals). Means sharing at least one letter are not significantly different $\left(\mathrm{T}_{\text {Tukey }} \geq 0.05\right)$. 


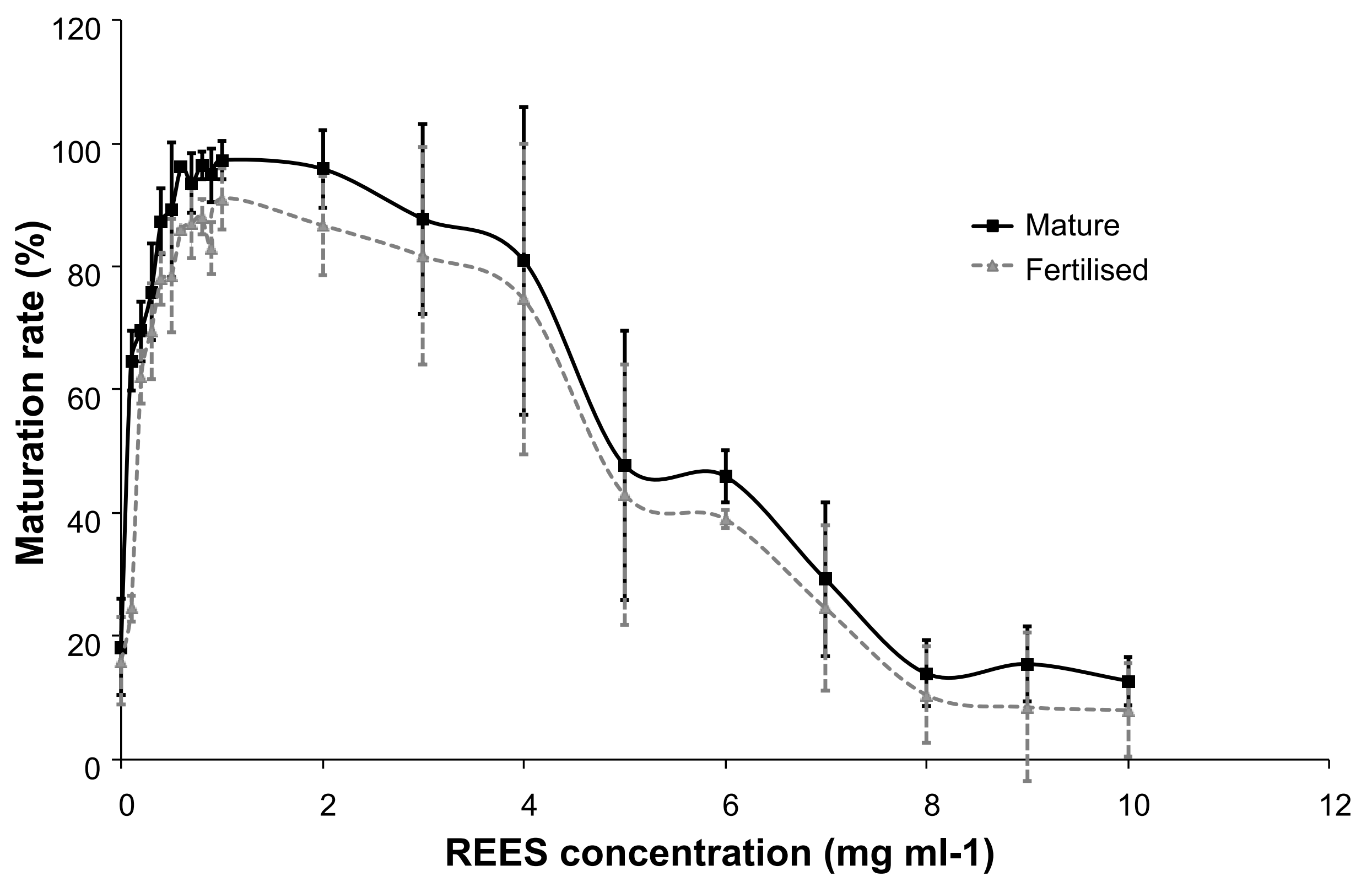




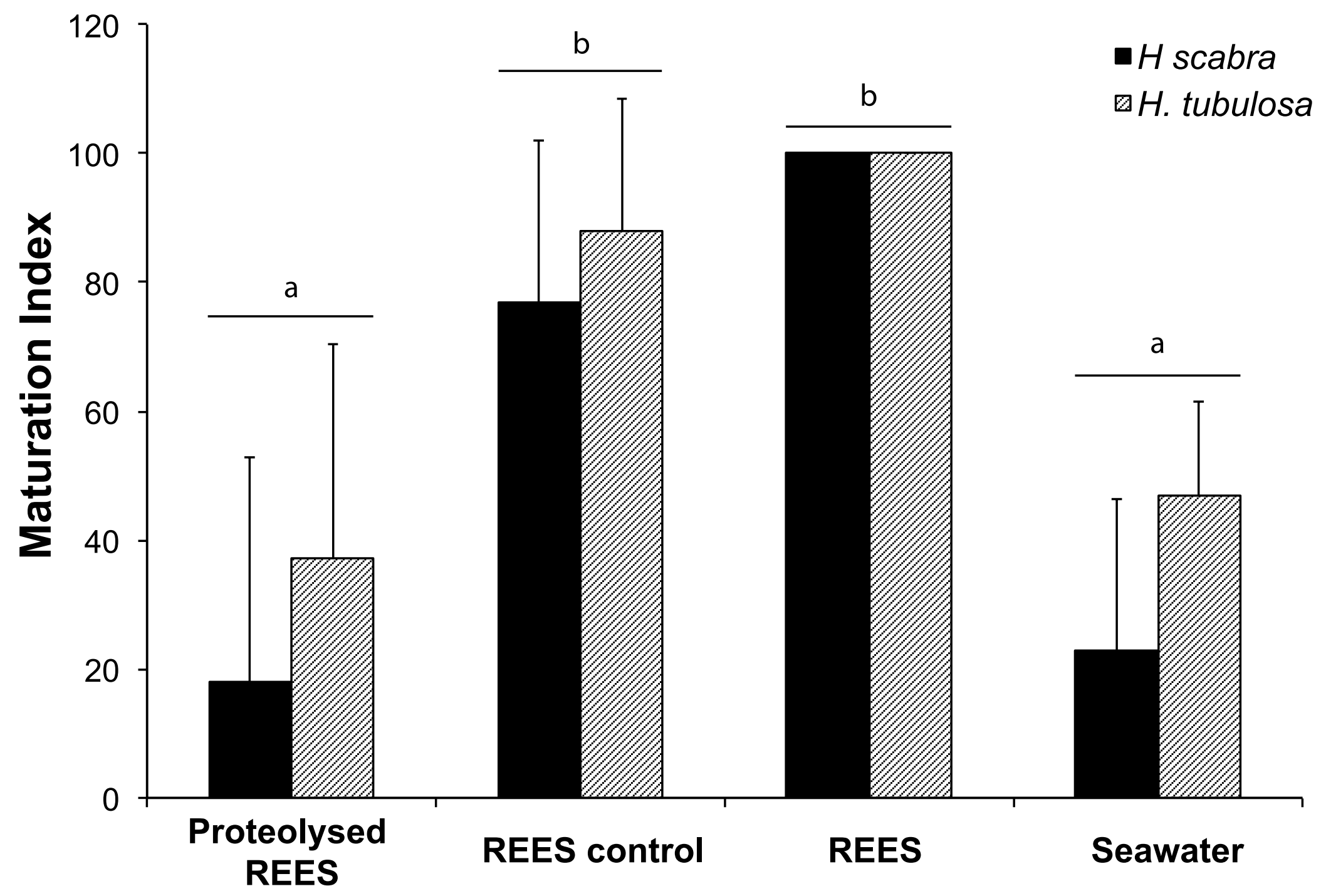




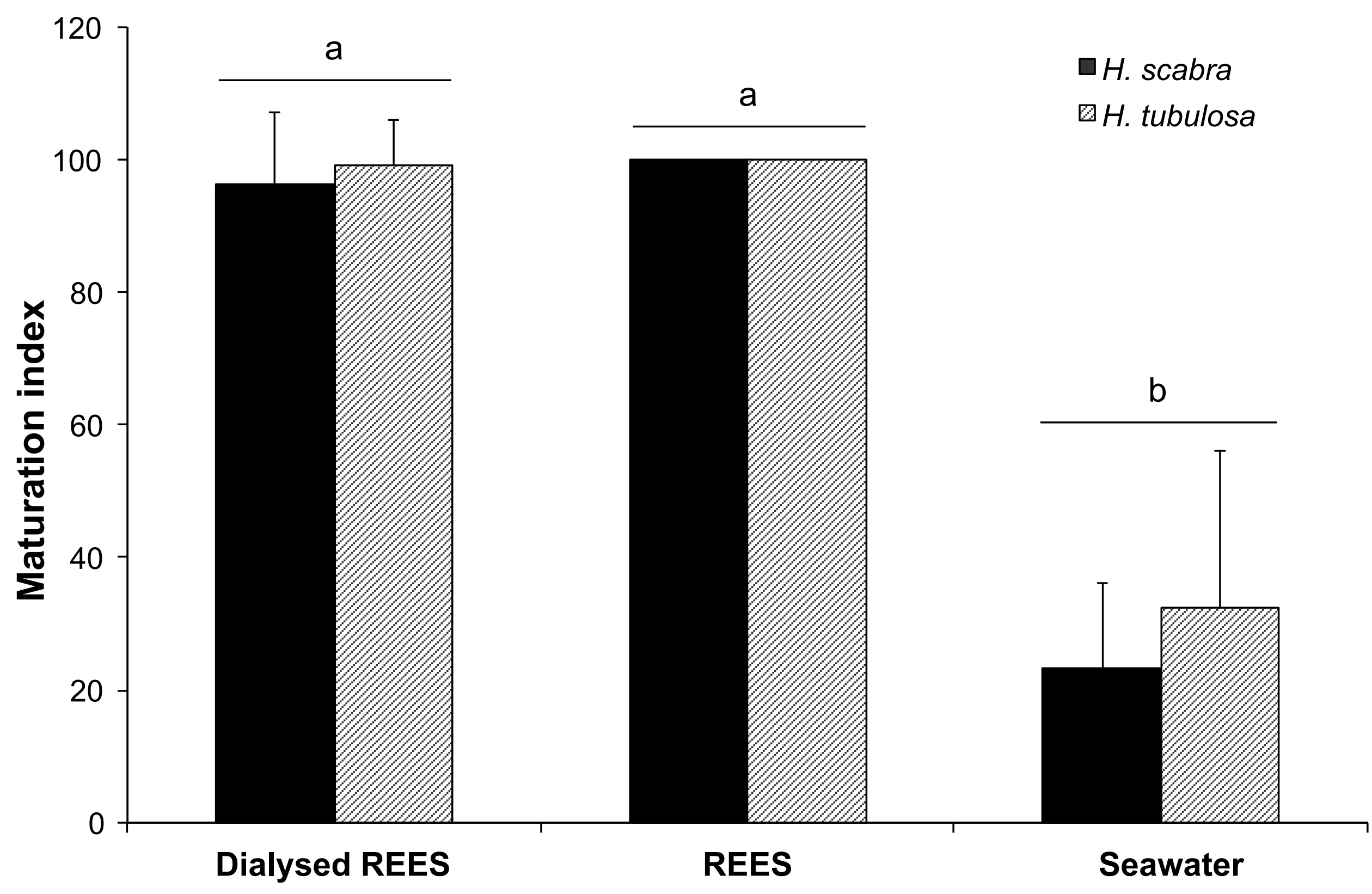




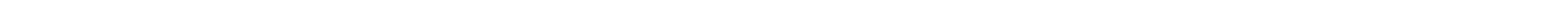




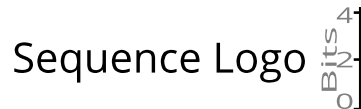

Strongylocentrotus purpuratus Apostichopus japonicus Salmo salar Xenopus laevis

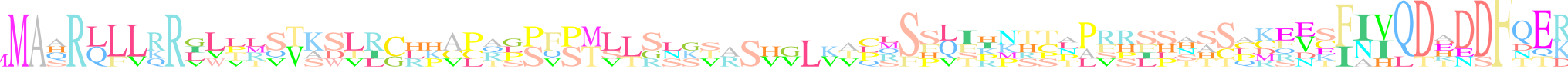
MAARQLLQRGLLRQTAWTLGRKVCQGPVPMVTGLKSASVVLVVQRFPQF INS SAPFHSS SHCLDENSF I I QDRDDFQEKVL PLSFISPKRTLPRSLPHTSCREVSFIVQDHEDFTEKVI Haliotis discus discus

AHR L L VRR I WTL S VKD LRCL PAPTS S F STSLR S ST - TPLSFLSPKRTLPRSLPHTSCREVSF IVQDHEDFTEKVI
$K A L S S S Q I H P H C N L R P I S T S T P C R V T F N V Q D A D D F Q E R V V$ Escherichia coli

MAQR L F L KR V LTSVK S I - APAPSFSTLLS
MMASRQ L LRRL VPMVTS SVRCHHCLRLPQPML-S

CQSHVTKMTTP P VRS LAASAKFEC I N I QDE DDFQQRVL

1110

120
$13+0$
150
MSDK I I HLTDDSFDTDVL 170
180

Strongylocentrotus purpuratus

Apostichopus japonicus
Salmo salar

Salmo salar

NSKSPV-I VDFHAEWCNPCK

KA L APVLDAVLQNTKGQVKLAKV

LAPVLDAVLQNTKGQVKLAKVD IDE L QDLA I GFGVDSVPTIMAFKGGQKVSKF I GNQSQEKVEAFVEKLLT
LAPRLTKALESVGDKVNLAKVDVDDNADLAMEYKVSSVPTVLFFKDGNH I DKF I GA I E QDR I E HY I EKYM

tis discus discus

NSELPV-L
GSETPV-VVD

I DFHAQWC GPCK |

L GPRLEKAVAKQKGKVAMAKVD

IDD

IG

Escherichia coli

VDFWAEWCGPCK

作

作 


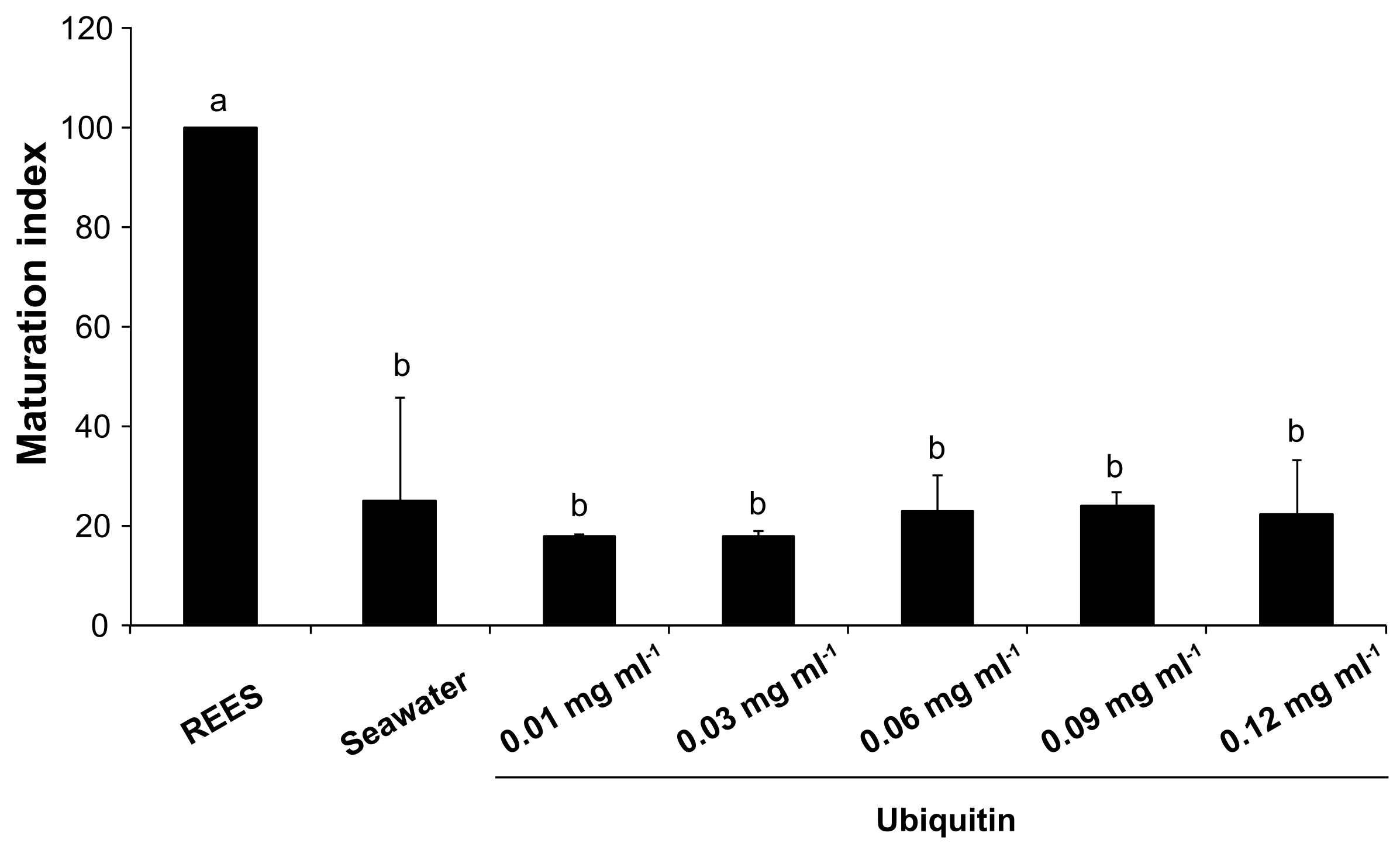




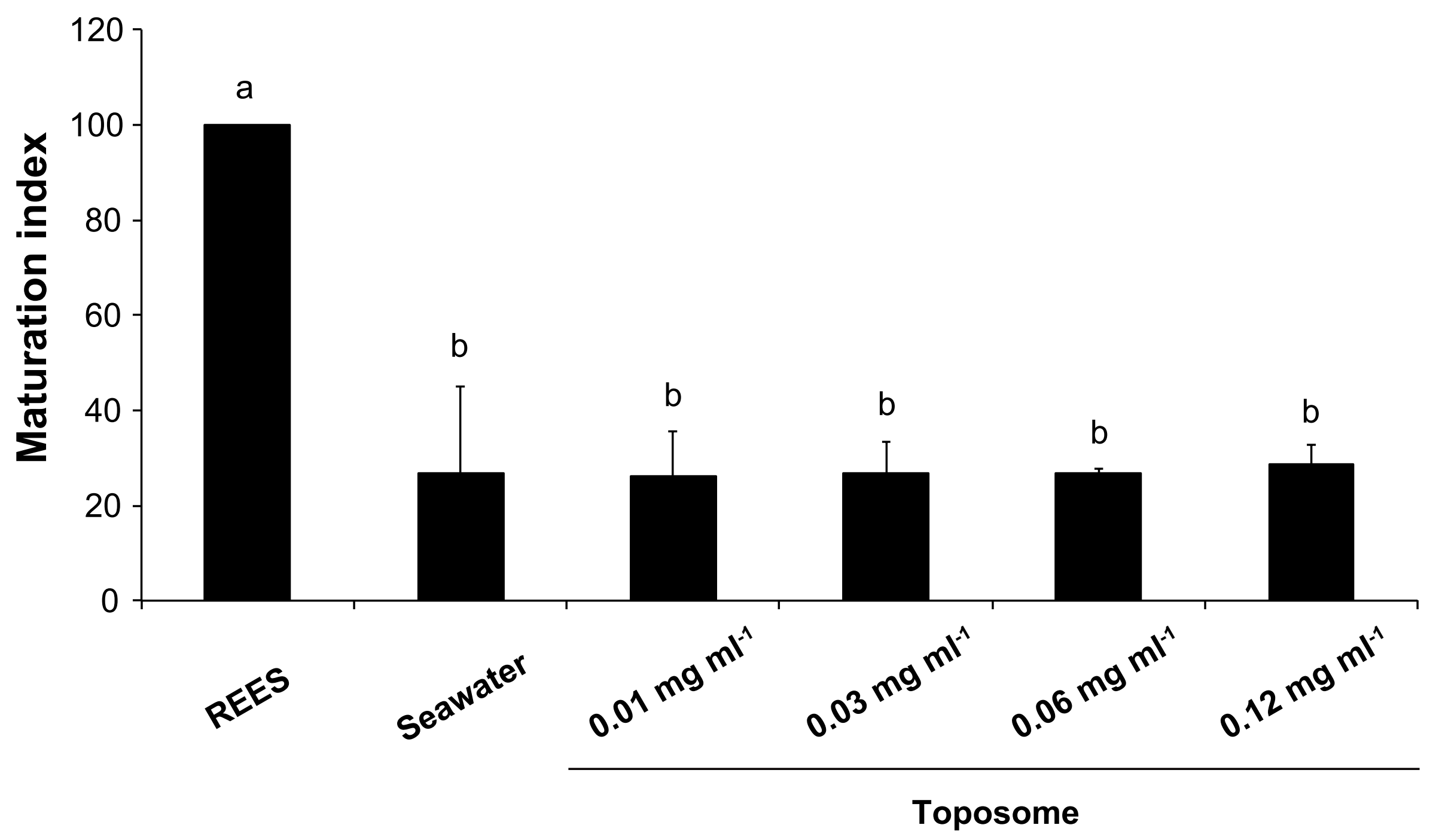




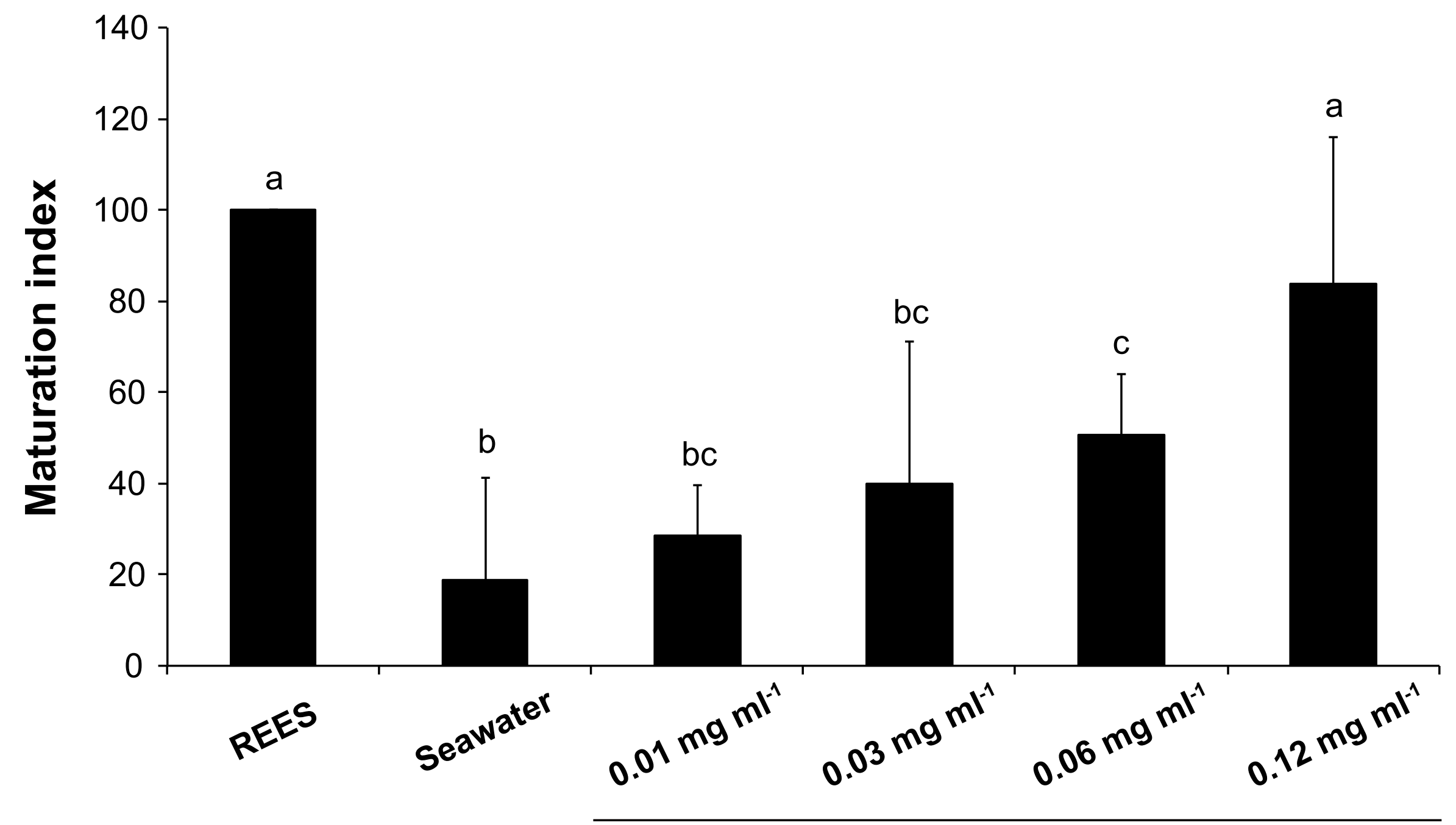

Thioredoxin 


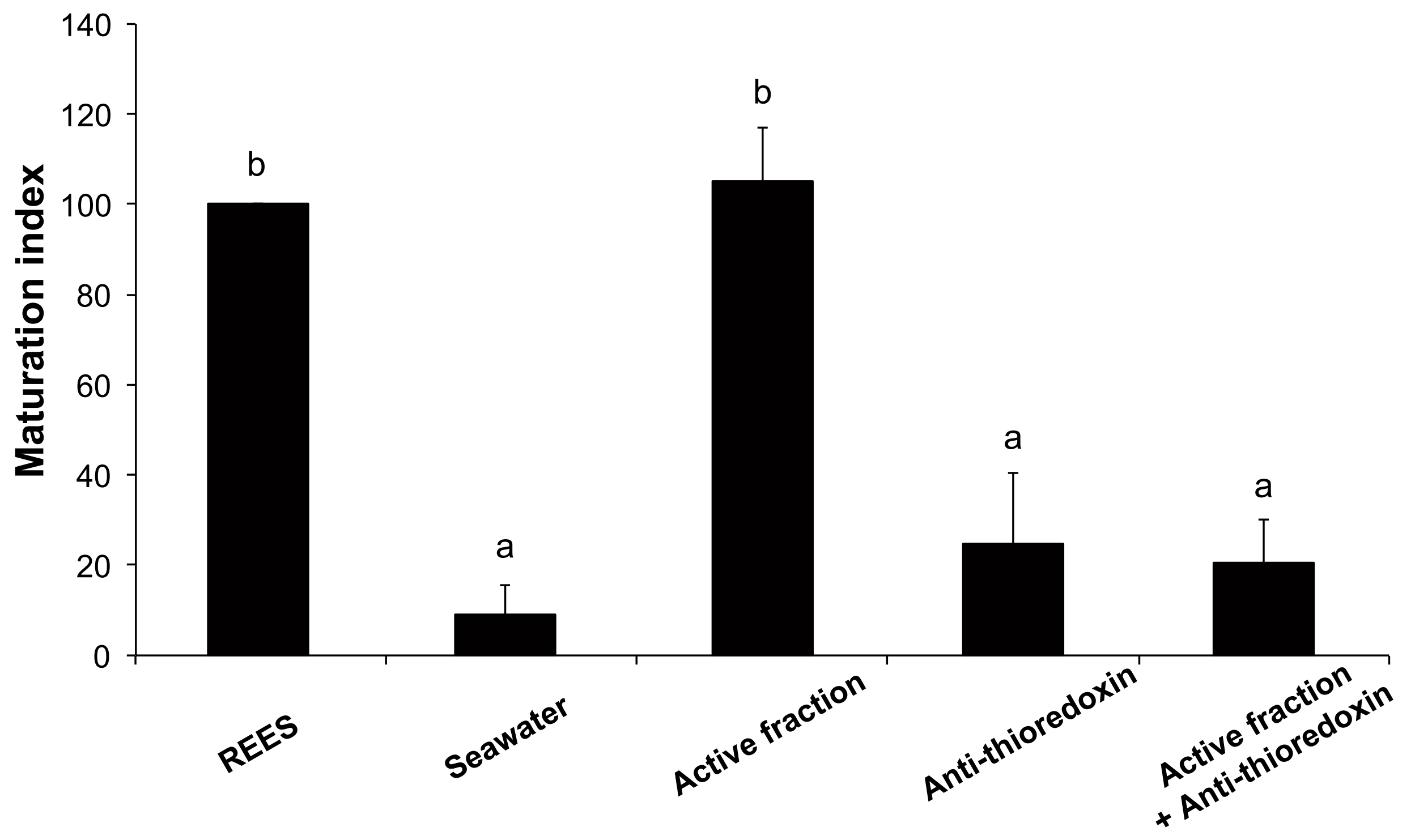




\section{SDS-Page}

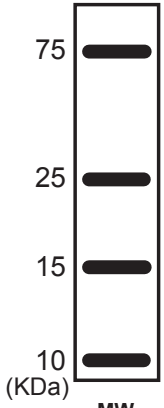

MW

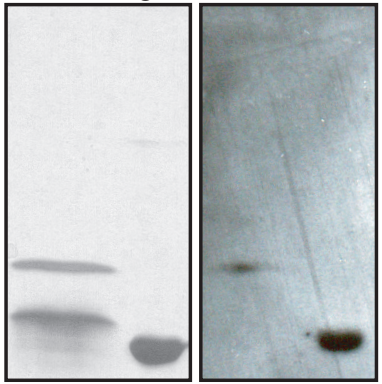

Active Trx from Active Trx from fraction E. coli fraction E. coli 
Table 1. Peptides obtained by nanoLC-MS/MS in active sample of REES. Identification of these peptides allowed to identify the protein present in REES. The score is the Mascot score.

\begin{tabular}{|c|c|c|c|c|}
\hline $\begin{array}{l}\text { Accession } \\
\text { numbers }\end{array}$ & Protein (Organism source) & MW (KDa) & Score & $\begin{array}{l}\text { Peptide } \\
\text { number }\end{array}$ \\
\hline gi|38147297 & Toposome (Tripneustes gratilla) & 15.6 & 314 & 13 \\
\hline gi|115650689 & $\begin{array}{l}\text { Similar to fibrillin-3 short from precursor transcript } \\
\text { variant } 1 \text { (Strongylocentrotus purpuratus) }\end{array}$ & 11.0 & 117 & 10 \\
\hline gi|72010707 & $\begin{array}{l}\text { Hypothetical protein isoform } 3 \text { (Strongylocentrotus } \\
\text { purpuratus) }\end{array}$ & 19.0 & 104 & 1 \\
\hline gi|72139704 & Similar to ubiquitin (Strongylocentrotus purpuratus) & 14.9 & 91 & 5 \\
\hline gi|1703135 & Actin, cytoskeletal 3A (Strongylocentrotus purpuratus) & 42.1 & 81 & 3 \\
\hline gi|115751537 & $\begin{array}{l}\text { Similar to epidermal growth factor II precursor } \\
\text { (Strongylocentrotus purpuratus) }\end{array}$ & 19.5 & 53 & 2 \\
\hline gi|115735345 & Hypothetical protein (Strongylocentrotus purpuratus) & No information & 35 & 2 \\
\hline
\end{tabular}

